$1-1-1981$

\title{
Tort Responsibility of Mentally Disabled Persons
}

James W. Ellis

University of New Mexico - School of Law

Follow this and additional works at: https://digitalrepository.unm.edu/law_facultyscholarship

Part of the Law Commons

\section{Recommended Citation}

James W. Ellis, Tort Responsibility of Mentally Disabled Persons, 1981 American Bar Foundation Research Journal 1079 (1981).

Available at: https://digitalrepository.unm.edu/law_facultyscholarship/568

This Article is brought to you for free and open access by the UNM School of Law at UNM Digital Repository. It has been accepted for inclusion in Faculty Scholarship by an authorized administrator of UNM Digital Repository. For more information, please contact amywinter@unm.edu, Isloane@salud.unm.edu, sarahrk@unm.edu.

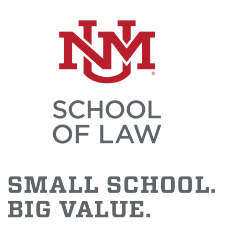

BIG VALUE. 


\section{Tort Responsibility of Mentally Disabled Persons}

James W. Ellis

The standard of care to be applied in tort cases involving mentally disabled people has not been reconsidered in recent years. Traditional rationales for the "objective" standard are less persuasive in the context of current legal approaches to the rights of mentally ill and retarded persons. Analogies to children (especially the concept of "mental age") and to physically handicapped adults merit reexamination.

\section{INTRODUCTION}

The past decade has witnessed a quantum leap in legal interest in the status of mentally ill and mentally retarded people, accompanied by dramatic changes in the substantive law regarding such persons. New statutes and case law have transformed the areas of commitment, ${ }^{1}$ guardianship, ${ }^{2}$ confidentiality, ${ }^{3}$ consent to treatment, ${ }^{4}$ and institutional condi-

James W. Ellis is Visiting Scholar, American Bar Foundation, and Associate Professor, University of New Mexico School of Law. A.B., 1968, Occidental College; J.D., 1974, University of California, Berkeley. The author is grateful for the research assistance of Paula Hanson and for the careful reading and criticism of the manuscript by Spencer Kimball and by Ted Occhialino, Professor of Law, University of New Mexico School of Law.

1. E.g., Addington v. Texas, 441 U.S. 418 (1979); Lynch v. Baxley, 386 F. Supp. 378 (M.D. Ala. 1974); Developments in the Law-Civil Commitment of the Mentally Ill, 87 Harv. L. Rev. 1190 (1974); Mental Health Law Project, Legal Issues in State Mental Health Care: Proposals for Change: Civil Commitment, 2 Mental Disability L. Rep. 73 (1977).

2. E.g., Mental Health Law Project, Legal Issues in State Mental Health Care: Proposals for Change: Guardianship, 2 Mental Disability L. Rep. 443 (1978); ABA Special Commission on the Mentally Disabled, Developmental Disabilities State Legislative Project, Guardianship \& Conservatorship: Statutory Survey; Model Statute (Discussion ed., Washington, D.C.: American Bar Association, June 1979).

3. E.g., Caesar v. Mountanos, 542 F.2d 1064 (9th Cir. 1976); Tarasoff v. Regents of Univ. of Cal., 17 Cal. 3d 425, 551 P.2d 334, 131 Cal. Rptr. 14 (1976); American Psychiatric Association, Confidentiality and Third Parties, Task Force Report No. 9 (Washington, D.C.: American Psychiatric Association, 1975); Mental Health Law Project, Legal Issues in State Mental Health Care: Proposals for Change: Therapeutic Confidentiality, 2 Mental Disability L. Rep. 337 (1977).

4. E.g., Rogers v. Okin, 478 F. Supp. 1342 (D. Mass. 1979) 634 F.2d 650 (1st Cir. 1980), cert. granted, 101 Ct. 1972 (1981); Aden v. Younger, 57 Cal. App. 3d 662, 129 Cal. Rptr. 535 (1976); Superintendent of Belchertown v. Saikewicz, 373 Mass. 728, 370 N.E.2d 417 (1977); Alan A. Stone, Mental Health and Law: A System in Transition 97-108 (New York: Jason Aronson, Inc., 1976); Robert Plotkin, Limiting the Therapeutic Orgy: Mental Patients' Right to Refuse Treatment, 72 Nw. U.L. Rev. 461 (1977). 
tions, ${ }^{5}$ to name just a few. Even the criminal responsibility of mentally disabled people, an area that cannot be said to have been neglected in previous decades, has undergone substantial change in recent years. ${ }^{6}$ Despite all this activity, questions involving the tort liability of the mentally disabled have received almost no attention.

Perhaps it should not be surprising that the issue of tort responsibility has not been reconsidered. There was certainly plenty of competition for a place on the agenda of the 1970s and for the attention of courts, legislators, scholars, and advocates. The flood of activity in mental disability law was generated in large part by a new specialty within the bar which addressed the problems of the mentally ill and mentally retarded. Tort issues could have been thought lacking in sex appeal, in comparison with some others. ${ }^{7}$ And the cases to raise those issues were not likely to be numerous. Mentally disabled persons as a class tend to be judgment proof; as plaintiffs, they seldom raise problems unique to their class. So perhaps it is to be expected that tort responsibility and its neglected siblings in the family of mental disability law (contractual rights and obligations, testamentary capacity, etc.) should have been left for reconsideration in the postdiluvian era.

Reconsideration is warranted, however. The mental disability cases of the 1970s have radically changed our view of the legal status of mentally disabled people, and those views now bear little resemblance to the historical attitudes that shaped the policies of the current tort law. An affirmation of the full citizenship status of mentally disabled people ${ }^{8}$ has accompanied a heightened solicitude for their welfare. ${ }^{9}$ A reconsideration of the rules of tort responsibility will suggest that these two praiseworthy attitudes may not be easy to translate into legal rules. If this rather unhappy hypothesis should be confirmed, it may give cause to reconsider the status of the mentally disabled under the law as a whole, and it may

5. E.g., Wyatt v. Aderholt, 503 F.2d 1305 (5th Cir. 1974); Pennhurst State School \& Hosp. v. Halderman, 101 Ct. 1531, 49 U.S.L.W. 4363 (1981); Jay Katz, The Right to Treatment-an Enchanting Legal Fiction? 36 U. Chi. L. Rev. 755 (1969); Charles R. Halpern, The Right to Rehabilitation in President's Committee on Mental Retardation, The Mentally Retarded Citizen and the Law 384 (New York: Macmillan Publishing Co., Free Press, 1976); N.M. Stat. Ann. § 43-1-7 (1979).

6. E.g., United States v. Brawner, 471 F.2d 969 (D.C. Cir. 1972); Herbert Fingarette \& Ann Fingarette Hasse, Mental Disabilities and Criminal Responsibility (Berkeley: University of California Press, 1979).

7. Exhuming the reasonable man might seem less attractive than righting outrageous injustice or establishing constitutional landmarks. E.g., O'Connor v. Donaldson, 422 U.S. 563 (1975) (successful attempt to right an outrageous injustice); Parham v. J.R., 442 U.S. 584 (1979) (failed attempt to right an outrageous wrong); Jackson v. Indiana, 406 U.S. 715 (1972) (establishing constitutional landmark).

8. See generally President's Committee on Mental Retardation, The Mentally Retarded Citizen and the Law (New York: Macmillan Publishing Co., Free Press, 1976).

9. E.g., Wyatt v. Stickney, 325 F. Supp. 781 (M.D. Ala. 1971), aff'd in relevant part sub. nom. Wyatt v. Aderholt, 503 F.2d 1305 (5th Cir. 1974). 
require of the courts and legislatures a greater sophistication of analysis in matters involving this group. A further reason for reconsideration may be found in the changing tort law itself. Rules governing the tort responsibility of the mentally disabled were developed, in large part, at a time when strict liability was widely accepted, and they were criticized (with remarkably little effect on the courts) when fault became the governing principle in negligence law. With the entrenchment of the fault principle and the advent of comparative negligence in many jurisdictions, the policy underpinnings of the current rules have weakened, if not collapsed. If the current rules are to be retained, new rationales must be developed or the old ones must be refurbished.

This article will examine the policy rationales for the traditional standard in the area of negligence. It will then consider the changes that have occurred in recent years and will evaluate possible analogies to the standard of care for children and for the physically handicapped.

\section{The ObJective Standard For Mentally Disabled Defendants}

\section{A. The Rule and Its Origin}

While under some circumstances mentally disabled ${ }^{10}$ people may be exonerated from responsibility and punishment for criminal acts they have committed, the common law has not extended the same dispensation for tortious acts. The general rule is that mentally disabled adults are to be held responsible for the torts they commit. ${ }^{11}$ The rule is almost invariably applied to both "intentional torts"'12 and acts of negligence.

This rule is remarkably well settled in this country. In some states the

10. This article will use the term "mentally disabled" to refer both to mentally ill and to mentally retarded people. See note 16 infra. The courts appear not to have drawn a distinction between these two groups.

11. McGuire v. Almy, 297 Mass. 323, 8 N.E.2d 760 (1937); Johnson v. Lambotte, 147 Colo. 203, 363 P.2d 165 (1961); William J. Curran, Tort Liability of the Mentally Ill and Mentally Deficient, 21 Ohio St. L.J. 52 (1960); American Law Institute, Restatement (Second) of Torts § 283B (1965).

12. See, e.g., In re Meyer's Guardianship, 218 Wis. 381, 261 N.W. 211 (1935) (arson); Morse v. Crawford, 17 Vt. 499, 44 Am. Dec. 349 (1845) (conversion); Krom v. Schoonmaker, 3 Barb. 647 (N.Y. 1848) (false imprisonment); Kaczer v. Marrero, 324 So. $2 d 717$ (Fla. App. 1976) (assault and battery).

Courts have had somewhat greater difficulty with cases of torts that require intent as a necessary element, such as malicious prosecution, alienation of affection, misrepresentation, and defamation. In the last category, compare Irvine v. Gibson, $117 \mathrm{Ky} .306,77 \mathrm{~S} . \mathrm{W} .1106$ (1904) (malice required), with Ullrich v. New York Press Co., 23 Misc. 168, 50 N.Y.S. 788 (1898) (no malice required). No cases have been found that consider the intent of mentally disabled defendants since the defamation area was constitutionalized in New York Times Co. v. Sullivan, 376 U.S. 254 (1964), and Gertz v. Robert Welch, Inc., 418 U.S. 323 (1974). The impact of Gertz on mentally disabled defendants is not yet clear, but it could be argued that its prohibition on defamation judgments in the absence of fault prohibits a court from finding liability where the defendant's mental disability negates the element of fault. 
principle is codified in statute, ${ }^{13}$ but more frequently it has been adopted by the courts. Its origin can be (and often has been) traced back to Weaver $v$. Ward, ${ }^{14}$ a seventeenth-century English case in which the statement of the rule is clearly dictum. ${ }^{15}$ It is not difficult to understand, in an environment of strict liability for torts, why the early courts found it unnecessary to excuse the tortious acts of "lunatics" or "idiots and imbeciles." " Since lack of moral blame was not sufficient to bar recovery from a mentally typical defendant (as in the case of an "unavoidable" accident), it would have made no sense to immunize the mentally disabled defendant because his actions were the product of his mental condition. Within the context of strict liability, the rule made sense irrespective of the law's (and society's) general view of the status and actions of mentally disabled people.

The issue became more difficult with the introduction of the fault principle of tort liability. ${ }^{17}$ With this development, the courts undertook the quasi-metaphysical task of assigning blame for individual actions, although the blame and its consequences differed from a finding of crimi-

13. E.g., Cal. Civ. Code $\S 41$ (West 1954); Mont. Rev. Codes Ann. § 27-1-711 (1979); N.D. Cent. Code $\S 14-10-03$ (1971); Okla. Stat. Ann. tit. $15 \S \S 25,26$ (West 1972); S.D. Comp. Laws Ann. § 27A-2-4 (1976).

14. Weaver v. Ward, 80 Eng. Rep. 284, Hob. 134 (1616).

15. The case did not involve any allegation of mental disability.

16. The terminology changes with remarkable frequency in this area. Early courts most frequently used the terms "idiot" and "imbecile" to describe persons who were mentally retarded. Sometimes the two were used interchangeably, and at other times they connoted a differentation of ability (higher functioning retarded people were classed as imbeciles). In the early years of this decade, professionals (mostly physicians) began using an additional term, "feeble-minded," to describe those with greater ability than imbeciles. All of these terms are now archaic, and their continued use by some courts is demeaning. Current usage categorizes the ability of retarded persons on a scale of profound, severe, moderate, and mild retardation. Until 1973, an additional category of "borderline" retardation was used to describe those with the smallest degree of disability. But the American Association on Mental Deficiency, the dominant professional organization in this field, voted to abolish that category, and persons previously labelled "borderline retarded"' are now generally viewed as falling within the normal range of intelligence, although they may still be called "slow learners" by the general public. See generally Herbert J. Grossman, ed., Manual on Terminology and Classification in Mental Retardation (Washington, D.C.: American Association on Mental Deficiency, 1977).

An even greater variety of labels have been applied to mentally ill persons over the years. Courts have referred to such persons as "mad," "lunatics," "insane," and "crazy," among numerous other terms. One difficulty that arises in interpreting early cases is that these terms were sometimes used to describe only those persons whom we would now consider mentally ill and at other times included both the mentally ill and mentally retarded. This is a particular problem in interpreting early statements of tort rules regarding liability of "the insane."

In current usage, the term "mentally disabled" most frequently is an umbrella term that refers to both the mentally ill and the mentally retarded. Care should be taken not to confuse it with "developmentally disabled," a term originating in federal statutes and adopted in many states to describe a variety of disabilities, the most common of which is mental retardation but which does not include mental illness.

17. See generally G. Edward White, Tort Law in America: An Intellectual History (New York: Oxford University Press, 1980). 
nal responsibility. The dilemma was thus posed: was it better to retain the rule of mentally disabled persons' responsibility from the old system of strict liability, or should something parallel to the criminal law's insanity defense be adopted for tortious acts? American courts in common law jurisdictions $^{18}$ identified the matter as a question of public policy and unanimously chose to retain the old rule. Despite substantial criticism from legal scholars, ${ }^{19}$ courts in intervening decades have not found sufficient reasons to overturn that choice. ${ }^{20}$

\section{B. Policy Rationales for the Rule}

Courts and commentators have suggested a number of policy rationales for the objective standard in cases involving mentally disabled defendants. While the formulations and combinations have differed somewhat, the most striking fact is that the reasons advanced have been so consistent over the past century. The rationales most frequently suggested are the following:

1) "[W]here one of two innocent persons must suffer a loss, it should be borne by the one who occasioned it." 21

2) Liability for negligent acts will encourage those who are responsible for mentally disabled persons (their families or guardians) to look after them and prevent them from doing harm. ${ }^{22}$

3) If mentally disabled people are to live in liberty in society, they should pay for the damage they cause. ${ }^{23}$

18. Louisiana, a civil law jurisdiction, does not follow the common law rule. Yancey v. Maestri, 155 So. 509 (La. Ct. App. 1934). See also La. Civ. Code Ann. art. 2319 (West 1979). Yancey contains an extensive discussion of the rule in other countries. For another comparative view, see Pamela Picher, The Tortious Liability of the Insane in Canada, 13 Osgoode Hall L.J. 193 (1975).

19. See, e.g., Melville Madison Bigelow, The Law of Torts 109 (8th ed. Boston: Little, Brown \& Co., 1907); Frederick Pollock, The Law of Torts: A Treatise on the Principles \& Obligations Arising from Civil Wrongs in the Common Law 35 (1st ed. Philadelphia: Blackstone Publishing Co., 1887); Francis H. Bohlen, Liability in Torts of Infants and Insane Persons, 23 Mich. L. Rev. 9 (1924); W. G. H. Cook, Mental Deficiency in Relation to Tort, 21 Colum. L. Rev. 333 (1921); Curran, supra note 11; Robert M. Ague, Jr., The Liability of Insane Persons in Tort Actions, 60 Dick. L. Rev. 211 (1956); Comment, The Tort Liability of Insane Persons for Negligence: A Critique, 39 Tenn. L. Rev. 705 (1972); Clarence Morris \& C. Robert Morris, Jr., Morris on Torts 51 (2d ed. Mineola, N.Y.: Foundation Press, 1980). For contrary views, see Thomas M. Cooley, A Treatise on the Law of Torts: Or the Wrongs Which Arise Independent of Contract 115-19 (2d ed. Chicago: Callaghan \& Co., 1888); George J. Alexander \& Thomas S. Szasz, Mental Illness as an Excuse for Civil Wrongs, 43 Notre Dame Law. 24 (1967).

20. In many jurisdictions, the courts appear not to have been asked. The reason for the small volume of appellate litigation is not altogether clear. The alternatives that distracted litigators specializing in mental disability law, as discussed above, would not have applied to personal injury lawyers.

21. Seals v. Snow, 123 Kan. 88, 90, 254 P. 348, 349 (1927). This reason is frequently cited in both early and recent cases.

22. McGuire v. Almy, 297 Mass. 323, 8 N.E. 2d 760, 762 (1937); George A. Smoot, The Law of Insanity 362-63 (Kansas City, Mo.: Vernon Law Books Co., 1929). This rationale is among the most frequently cited in the early cases.

23. Restatement (Second) of Torts $\$ 283 B$, Comment b(3) at 17 (1965); Schumann v. Crofoot, 43 Or. App. 53, 602 P.2d 298, 300-301 (1979). 
4) Mental disability is easily feigned, and defendants might choose such an act of duplicity to avoid liability. ${ }^{24}$

5) It is difficult for courts to distinguish between "true" mental disability and variations in temperament, intellect, and emotional balance, and to allow all such differences to serve as excuses would erode the objective standard in all cases. ${ }^{25}$

6) The insanity defense and the doctrine of diminished capacity have wreaked havoc in the field of criminal law, and this chaos should not be recreated in tort law. ${ }^{26}$

While the first of these rationales is merely a restatement of the doctrine of strict liability, the others warrant closer inspection. The second and third raise important questions about the proper place of mentally disabled people in society; the remaining three speak to the nature of tort theory and the administration of tort cases.

\section{The Rationales Reconsidered}

The contention that mentally disabled defendants should be held liable because liability will serve as an incentive to greater care on the part of their custodians is among the most frequently cited rationales. It appeared in the early discussion of the subject and has not been abandoned. Its sufficiency as a support for the objective standard is limited because it presupposes a greater control over the acts of mentally disabled people than is exercised by any but the most draconian of caretakers. Even if relatives and guardians did exercise a sufficient amount of power over the disabled individual, those employing this rationale must believe the operant motivation to be fear that tort liability will reduce the individual's estate (and thus, in the case of relatives, their ultimate inheritance from that estate). ${ }^{27}$. This belief may be somewhat less than realistic. History records many strenuous efforts by guardians and relatives to restrain the

24. "So deep is the cunning of the evil doer that it is extremely difficult to detect the ruse, when he is feigning insanity as a cloak under which he may safely work his nefarious ends. The rule is therefore necessary, in order that the evil doer may not be led to simulate madness as a means of escaping the consequence of his tortious acts." Smoot, supra note 22, at 363. "[I]f parties can escape the consequences of their injurious acts upon the plea of lunacy, there will be a strong temptation to simulate insanity, with a view of masking the malice and revenge of an evil heart." McIntyre v. Sholty, 121 III. 660,13 N.E. 239,240 (1887).

25. Restatement (Second) of Torts, § 283B, Comment b(1) at 17 (1965). See also Olliver] W[endell] Holmes, Jr., The Common Law 108 (Boston: Little, Brown \& Co., 1881).

26. Jolley v. Powell, 299 So. 2d 647, 649 (Fla. App. 1974); William L. Prosser, Handbook of the Law of Torts 1001 (4th ed. St. Paul, Minn.: West Publishing Co., 1971).

27. If an incentive for caretakers were thought desirable, an action for negligent supervision would probably be more effective. An interesting, if tangential, modern parallel is the current controversy over the liability of psychiatrists and mental facilities for the tortious acts of their patients. See Tarasoff v. Regents of Univ. of Cal., 17 Cal. 3d 425, 551 P.2d 334, 131 Cal. Rptr. 14 (1976). It has been suggested that creation of this third-party liability will dissuade therapists from treating patients who might prove abnormally prone to commit tortious acts. Alan A. Stone, The Tarasoff Decisions: Suing Psychotherapists to Safeguard Society, 90 Harv. L. Rev. 358 (1976). 
liberty and actions of mentally ill and retarded persons, but it seems likely that alternative incentives (concern for the disabled individual, embarrassment of the relatives, fear, revulsion, concern for society, etc.) were probably sufficient to keep most, if not all, from even considering the possibility of tort liability.

More relevant to the present analysis than the rationale's impracticality is the underlying attitude it reveals. In 1879 Cooley advanced this argument and supported it by noting that "the State at large is deeply concerned in having all incompetent persons in charge of competent and responsible guardians, whose business it shall be to care for them and to guard both them and the public against such injuries as would be likely to result from their condition." ${ }^{28}$ By the late nineteenth century it was not a matter of indifference to society whether the mentally disabled were under some form of effective control. This was a time in which mentally disabled people were seen as a threat to society, both through their own wicked actions and through the likelihood that they would "swamp" society with their "incompetence" if allowed to reproduce. ${ }^{29}$ This fear developed more fully in the early decades of this century into the eugenics movement, which insisted that such calamities could be averted only if the mentally disabled were both sterilized and segregated from society. ${ }^{30}$ In an era when numerous laws were passed to sterilize the mentally defective and to isolate them for life in institutions, it should not be surprising that courts were comfortable with a rule that was thought to increase the incentive to remove such troublesome people from active participation in society. If the fear of tort liability induced relatives or guardians to institutionalize a disabled person (or at least keep him strictly supervised at home), it was thought that everyone would benefit.

The same attitude can be seen in the statement, found in the Restatement (Second) of Torts, that "[m]ental defectives, if they are to live in the world, should pay for the damage they do." 31 The tone of the Institute's statement betrays, at best, a grudging acceptance of the fact that mentally disabled people do, in fact, live in the world. This reluctance

28. Cooley, supra note 19 , at 117.

29. Wolf Wolfensberger, The Nature and Origin of Our Institutional Models (Syracuse, N.Y.: Human Policy Press, 1975).

30. Id. See Marvin Rosch, Gerald R. Clark, \& Marvin S. Kivitz, eds., The History of Mental Retardation (Baltimore, Md.: University Park Press, 1976); Leo Kanner, A History of the Care and Study of the Mentally Retarded (Springfield, Ill.: Charles C. Thomas, Publisher, 1964); Kathleen Jones, A History of the Mental Health Services 182-225 (Boston: Routledge \& Kegan Paul, Ltd., 1972); Albert Deutsch, The Mentally III in America: A History of Their Care and Treatment from Colonial Times 332-86 (2d ed. rev. \& enl. New York: Columbia University Press, 1949).

31. Restatement (Second) of Torts § 283B, Comment b(3) at 17 (1965). 
mirrors the attitude of the early court decisions..$^{32}$ But the unwillingness to accept the full liberty of mentally disabled people should not be attributed to a mere lack of charity or sympathy on the part of the courts that adopted the objective standard. The conventional wisdom of the time, buttressed by what appeared to be a substantial body of scientific opinion, held that mentally ill and mentally retarded people constituted a grave threat to society. It is not surprising that such an atmosphere would foster a rule that refused to absolve such persons from compensating victims for the damage they caused.

Another common rationale for courts' adoption of the objective rule is the argument that a subjective rule would invite tortfeasors to feign insanity or retardation in order to escape liability. Whereas the previous argument was a guard against the evil done by the mentally disabled themselves, this view urged similar caution against those who might falsely claim such disability. To evaluate the continuing validity of this rationale, two separate issues must be considered.

The first consideration is whether current scientific and medical knowledge have advanced sufficiently to allow more accurate diagnosis and thus detection of false claims of disability. It is certainly true that the understanding of mental illness and retardation at the time of the formulation and adoption of the objective rule was much more primitive than our current state of knowledge. Great effort has been expended to advance our understanding of the etiology and course of various kinds of mental disability. The subtlety and complexity of the classification systems currently used by professionals suggest the scope of the advances made in the last half-century. ${ }^{33}$

There has been some suggestion that these advances may warrant reconsideration of the objective rule because uncertainty of diagnosis has been reduced so substantially. ${ }^{34}$ Whether these advances have been sufficient to outweigh the fear of uncertainty in individual cases is open to debate. Despite the elaborate structure of the American Psychiatric Association's new classification system, it remains true that diagnosis of mental illness is a most imprecise exercise. And while mental retardation might appear to be more amenable to objective measurement since a

32. While resistance to the notion of mentally ill and mentally retarded people living at liberty in the community has not vanished, its expression in law seems an anachronism in an era when legal rights of mentally disabled people have expanded so dramatically. Thus the court's reference to this rationale, citing the Restatement's commentary, is particularly jarring in the recent case of Schumann v. Crofoot, 43 Or. App. 53, 602 P.2d 298, 300 (1979).

33. Grossman, supra note 16; American Psychiatric Association, Diagnostic and Statistical Manual of Mental Disorders (3d ed. Washington, D.C.: American Psychiatric Association, 1980).

34. "Although this factor may be of decreasing importance with the continued development of medical and psychiatric science, it remains at the present time a major obstacle to any allowance for mental deficiency." Restatement (Second) of Torts, § 283B, Comment b(2) at 17 (1965). 
quantifiable measure (the IQ score) is potentially available for each individual, this precision is more apparent than real. Mental retardation consists of a combination of subaverage intellectual functioning with substantial problems in adaptive behavior, ${ }^{35}$ and each of these elements may be open to debate in any individual case. ${ }^{36}$ Perhaps the best conclusion that can be reached is that many individuals can be identified with some certainty as mentally ill or mentally retarded but that for a substantial number expert opinion is unlikely to be unanimous.

In evaluating the argument about feigned disability, we must consider not only the state of the diagnostic art but also the likelihood that a significant number of tort defendants would seek the protection of a false claim of mental disability. There appear to be no directly applicable empirical data on this issue. It will certainly be contended that the existence of questionable claims of insanity by criminal defendants indicates that a subjective standard in tort law would produce similar results. However, it is not intuitively obvious that the criminal law's experience would be repeated. A label of mental illness or mental retardation carries with it a substantial stigma in our society. While some criminal defendants may be willing to assume the stigmatizing effect of such a label in order to escape the death penalty or even lengthy imprisonment, it does not necessarily follow that tort defendants would be equally willing when money damages are the only penalty at issue. The fact that many tort defendants are substantially insured to cover the cost of an adverse judgment further mitigates the concern about false claims of mental disability. Perhaps the experience of contract law would be as useful for comparison as the criminal defense analogy; it has not been contended that the rule that mentally incompetent people may escape some of the obligations of their contracts has led to a large number of false claims of mental incapacity. It seems unlikely that false claims by tort defendants would present an insurmountable problem if a subjective tort standard were thought otherwise desirable.

A more serious concern is the contention that a subjective rule would be unmanageable because of the subtle variations of intelligence, temperament, and emotional balance which are common to all people and thus to all tort defendants. This argument contends that since we hold defendants who have unusually slow reflexes to the standard of the averagereflex reasonable person, it is no more unfair to hold the mentally deficient defendant to the standard of the mentally typical citizen. Holmes's

35. Grossman, supra note 16.

36. Disabilities in adaptive behavior are, not surprisingly, quite difficult to quantify. But disputes may also arise concerning the measurement of intellectual ability, such as the appropriateness of the chosen test to the status of the individual litigant and the proper interpretation of the resulting score. 
frequently quoted explanation of the reasonable person standard makes the point:

The law takes no account of the infinite varieties of temperament, intellect, and education which make the internal character of a given act so different in different men. It does not attempt to see men as God sees them, for more than one sufficient reason. . . . (W)hen men live in society, a certain average of conduct, a sacrifice of individual peculiarities going beyond a certain point, is necessary to the general welfare. If, for instance, a man is born hasty and awkward, is always having accidents and hurting himself or his neighbors, no doubt his congenital defects will be allowed for in the courts of Heaven, but his slips are no less troublesome to his neighbors than if they sprang from guilty neglect. ${ }^{37}$

Inevitably, an objective tort standard sacrifices fairness to those defendants who were incapable of meeting that standard but who did their subjective best, in favor of compensating plaintiffs where a typical person in the defendant's situation would have had sufficient skill to avoid the injury. Proponents of the objective standard for mentally disabled defendants can argue that its relaxation would introduce into tort law new inequities between mentally disabled defendants, who would escape liability, and defendants whose disability (e.g., congenital awkwardness accompanied by typical or superior intelligence) was not in the category afforded subjective treatment in the courts.

Debate on this point would be more clear-cut if other instances of subjectivity had not already been introduced into negligence law-for example, children and physically disabled people. ${ }^{38}$ In making allowances for these particularly appealing tort defendants, the law has abandoned a stance in which full equity can be achieved short of adoption of a subjective standard for all defendants, no matter what sort of uncontrollable disability they might claim (poor education, absent-mindedness, pathological lack of consideration for their fellow human beings, or whatever). Since the law certainly is unwilling to go this far in accommodating the varieties of human nature (both for administrative reasons and because of the presumed reduction in compensation to injured plaintiffs), any claim for a subjective standard for mentally disabled defendants will have to stand on a perception of extraordinary injustice to such defendants and on assurances that such a standard would not be unworkable.

This leads to the final point in defense of the objective standard-that its abandonment would produce the same immense difficulties encountered by the criminal law in the administration of the insanity

37. Holmes, supra note 25 , at 108.

38. Restatement (Second) of Torts $\S \S 283 \mathrm{~A}, 283 \mathrm{C}$ (1965). For a fuller discussion of analogies to the physically handicapped and to children, see text accompanying notes 67-93 infra. 
defense. It has already been suggested ${ }^{39}$ that the fear of feigned-insanity defenses in tort cases may not be warranted. But this does not eliminate the overall comparison with the criminal defense, a comparison that is of great concern to the courts. ${ }^{40}$ Even if every claim of mental disability were raised by a tort defendant who truly believed himself entitled to the defense, serious definitional problems would remain. What kinds of mental disability would be considered sufficient to provide a defense, and what kinds would be viewed as mere variations within the normal range and thus treated within the objective context? Here the parallel to the criminal insanity defense is apt. Much ink has been spilled on the merits of the M'Naghten rule (knowing right from wrong) as contrasted to an irresistible impulse rule, as contrasted to a "product of mental disease" rule, as contrasted to other formulations and combinations. ${ }^{41}$ The causal link between the mental disability and the allegedly tortious behavior must be established in any event, and that is a matter which is not without its own difficulties of definition and proof. But among those cases in which causation is established, it is likely that the law would demand (as it does in the criminal field) that the disability involved be of sufficient magnitude or of a particular type to warrant exoneration from responsibility for torts. Therefore individual cases would inevitably raise issues of measurement and classification which would be difficult and costly to resolve.

In answer to this argument, advocates of a subjective standard for the mentally disabled must surely acknowledge the difficulties inherent in such adjudications. But the criminal law is not the only context in which an individual's mental state is relevant to litigation under current law. Cases involving guardianship, commitment, testamentary capacity, and numerous other areas call upon triers of fact to decide whether an individual's mental condition warrants (or warranted) treatment different from that which the law affords to mentally typical persons. Both expert testimony and the fact-finder's own common-sense understanding of the individual's condition as illuminated by the evidence are commonly brought to bear in deciding these cases. Such adjudication is seldom neat or clear-cut, but the law has proven tolerant of a certain amount of evidentiary and doctrinal untidiness in the area of mental health law, if only because it has discovered no practical alternative that is at the same time fair to mentally disabled people. Proponents of a subjective stan-

39. See text accompanying notes 33-35 supra.

40. E.g., Jolley v. Powell, 299 So. 2d 647, 649 (Fla. App. 1974).

41. Among the best discussions is Abraham Samuel Goldstein, The Insanity Defense (New Haven, Conn.: Yale University Press, 1967). 
dard can argue that a new rule would offer no greater difficulties than are encountered in these old civil contexts.

In conclusion, it cannot be denied that the original policy rationales that led to the adoption of the objective standard and the rejection of an "insanity defense" in tort cases have been substantially weakened by a variety of legal and scientific developments in recent years. But it is also true that changing the rule to a subjective standard would carry difficulties of administration, and these will appear sufficient to some observers to support retention of the old rule even without its original supporting arguments, Others will disagree. But a reconsideration of this question cannot rest on the outcome of this debate alone, because related tort doctrines concerning the actions of tort plaintiffs have also been undergoing change, and the effect of these changes must also be weighed in the balance.

\section{Contributory Negligence and Comparative Negligence}

\section{A. The Subjective Standard for Contributory Negligence}

Given the longevity and near unanimity of the American rule that mentally disabled people are responsible for the torts they commit, it is somewhat surprising that courts have been nearly as unanimous in reaching a quite different conclusion in cases of alleged contributory negligence. At least for those mentally disabled plaintiffs who are "totally insane" the standard of care (self-protection) for claimed contributory negligence will be gauged to their individual capability. ${ }^{42}$ Thus the courts have created an objective rule for defendants, while for at least a substantial number of plaintiffs they have fashioned a subjective standard.

A subjective test for contributory negligence of mentally disabled plaintiffs first appeared as dicta during the last century. ${ }^{43}$ Its adoption, also in dicta, by the Supreme Court in 1900,44 and more clearly by the Ninth Circuit in $1911,{ }^{45}$ was followed by general acceptance in American courts. As announced in the Ninth Circuit case, the general principle is that plaintiffs who lack the average adult's intelligence and capacity to

42. E.g., Noel v. McCaig, 174 Kan. 677, 258 P.2d 234 (1953); Emory University v. Lee, 97 Ga. App. 680, 104 S.E. $2 d 234$ (1958). See Note, Contributory Negligence of Incompetents, 3 Washburn L.J. 215 (1964).

43. E.g., Boland v. Missouri R.R., 36 Mo. 484 (1865) (dicta regarding mental disability; the case dealt with a young child); Chicago \& Alton R.R. v. Becker, 76 Ill. 25 (1875).

44. Baltimore \& Potomac R.R. v. Cumberland, 176 U.S. 232 (1900) (this case also involved a child).

45. Seattle Electric Co. v. Hovden 190 F.7 (9th Cir. 1911). This case did involve an adult who appears to have been mentally retarded, but the statement of the rule, while clear, is technically dictum because the court also concludes that plaintiff's actions would not have been contributorily negligent "even if she had been possessed of ordinary capacity and intelligence." $190 \mathrm{~F}$. at 9. 
care for themselves will be held to the exercise of only such capability as they actually possess. ${ }^{46}$ Although some other courts have extended this subjective standard to only a subclass of mentally disabled plaintiffs, ${ }^{47}$ the abandonment of the reasonable person test for at least some mentally ill and retarded litigants is well accepted.

Why the courts have chosen to treat mentally disabled plaintiffs so differently from similarly situated defendants has not been explained clearly. One suggestion is that the policy rationales underlying the objective standard for a defendant's liability are less applicable in cases of claimed contributory negligence. ${ }^{48}$ This may be true for those rationales that are related to the strict liability origins of the rule (e.g., that the mentally disabled should pay for the damage they cause), but the differences between disabled plaintiffs and defendants are less clear when the courts are concerned with administrative issues (feigned insanity, definition of sufficient disability to fall within the subjective rule, and the courts' painful experience with the criminal insanity defense). But since the modern persuasiveness of the combined policy rationales for the objective standard is less than overwhelming, their lack of congruence in contributory negligence cases seems an insufficient explanation for what are essentially opposite rules.

A more likely explanation may derive from the view that contributory negligence is essentially an equitable bar against plaintiffs with "unclean hands." 49 Since an injured plaintiff who failed to protect himself because of mental disability cannot be said to be morally unworthy of the court's solicitude, compensating this "innocent" plaintiff from the purse of a "guilty" defendant produces little equitable discomfort. Since the doctrine of contributory negligence has long labored under criticism that it produces harsh results, ${ }^{50}$ the courts may have been willing to adopt a subjective standard for mentally disabled plaintiffs in order to avoid one set of harsh results for which there was little identifiable support in perceived fairness or public policy.

A related interpretation suggests that the mentally disabled plaintiff and defendant evoke very different degrees of sympathy from the court. The mentally ill or retarded defendant has somehow been allowed to live uncontrolled (or insufficiently controlled) in the world and has as a result

46. Id.

47. See text accompanying notes 52-64 infra.

48. The reasons "may not have the same force as applied to contributory negligence." Restatement (Second) of Torts $\S 464$, Comment $g$ at 509 (1965). See also, Comment, The Tort Liability of Insane Persons for Negligence: A Critique, 39 Tenn. L. Rev. 705, 722 (1972).

49. For a discussion of the various theories of contributory negligence, see Prosser, supra note 26, at $417-18$.

50. Thus the current movement to replace contributory negligence with a system of comparative negligence. See text accompanying note 65 infra. 
caused the kind of injury of which society is fearful. If that defendant has a sufficient estate to pay a tort judgment, the court may not see him as "entitled" to keep that money. ${ }^{\text {s1 }}$ It may be money that he did not earn (e.g., an inheritance) and it may be thought that it is money that he cannot profitably use (for if he is placed under greater control-i.e., in an institution-he will have no great "need" for funds). From such a perspective it may not seem unjust that that money be used to compensate the disabled person's victim. The mentally disabled plaintiff presents a far more sympathetic picture. He did not cause another person injury and only "caused" his own in the sense that he was less able to protect himself than a mentally typical person would have been. The potential judgment constitutes money that he truly "needs" for such things as medical bills occasioned by the injury. The plaintiff's disability, which may be identical to the defendant's in the previous hypothetical example, is considerably less threatening to society and may appear to have a superior claim to the court's sympathy.

Whatever the true explanation for the existence of a subjective standard in contributory negligence cases, the rule stands as a sharp and puzzling contrast to the standard for defendants.

\section{B. Dispute Over the "Partially Disabled" Plaintiff}

The fact that the courts have been nearly unanimous in fashioning a subjective test for contributory negligence should not be allowed to obscure the fact that jurisdictions differ as to which mentally disabled plaintiffs are entitled to its protection. Beginning with early cases that involved injuries to mentally disabled workers at their place of employment, ${ }^{52}$ some American courts have extended the benefits of the subjective standard to plaintiffs who are "totally insane" or "utterly devoid of intelligence" $" s 3$ but have denied them to individuals whose disability falls somewhat short of those characterizations.

In a leading early case, Worthington $v$. Mencer, ${ }^{54}$ the Alabama Supreme Court reversed a judgment for an injured worker who had claimed mental disability in response to a defense of contributory negligence. The court stated:

51. "[I]t is better that their wealth, if any, should be used to compensate innocent victims than that it should remain in their hands." Schumann v. Crofoot, 43 Or. App. 53, 602 P.2d 298, 301 (1979), citing Restatement (Second) of Torts $\$ 283 \mathrm{~B}$, comment b (1965).

52. E.g., Deisenrieter v. Kraus-Merkel Malting Co., 97 Wis. 279, 72 N.W. 735 (1897); Georgia Cotton-Oil Co. v. Jackson, $112 \mathrm{Ga} .620,37$ S.E. 873 (1901).

53. In most of the cases, the terminology is imprecise. Some courts appear to believe that some level of mental retardation can be labeled "devoid of intelligence" and some level of mental illness can be identified as "total insanity." See note 16 supra. No case appears to rest any distinction on the difference between mental illness and mental retardation.

54. Worthington v. Mencer, $96 \mathrm{Ala} .310,11$ So. 72 (1892). 
The plaintiff is to be held to the exercise of the degree of care of which he was capable. If he was merely a person of dull mind, who could labor for his own livelihood, and there was no apparent necessity of putting him under the protection of a guardian to keep him out of harm's way, he is chargeable with the same degree of care for his personal safety as one of brighter intellect, as any attempt to frame varying rules of responsibility to varying degrees of intelligence would necessarily involve confusion and uncertainty in the law. If, on the other hand, he was so absolutely devoid of intelligence as to be unable to apprehend apparent danger, and to avoid exposure to it, he cannot be said to have been guilty of negligence, because he was incapable of exercising care. ${ }^{55}$

Thus the reason for limiting plaintiffs' access to the subjective test were similar to the reasons for its rejection when claimed by mentally disabled defendants.

But the Alabama court's explanation also reveals other considerations. The "person [plaintiff] of dull mind" mentioned by the court cannot avail himself of the subjective test because he is capable of working for a living and is not in need of a guardian or the protection of an institution. Except for the court's mention of "confusion" and "uncertainty," the relevance of a plaintiff's employability is not readily apparent. But in the final quoted sentence, the court may offer clarification. It states that persons with greater disability ("absolutely devoid of intelligence") are unable to recognize potentially dangerous situations and to protect themselves. This suggests that the court's reluctance to compensate the less disabled plaintiff may spring from disbelief that his failure to protect himself was the result of his disability. The more severely disabled are "incapable of exercising care." This may imply that the less disabled are not entitled to protection from a defense of contributory negligence because they probably were, in fact, contributorily negligent, even if measured by a subjective standard.

The same skepticism about the relationship between plaintiff's disability and the accident can be seen in the recent case of Fox v. City and County of San Francisco. ${ }^{56} \mathrm{Mr}$. Fox, a mentally retarded adult, was injured when his bicycle collided with a municipal bus. The Court of Appeal reversed a judgment for plaintiff and discussed the appropriate standard of care for retarded plaintiffs at some length. It concluded that an objective standard was appropriate to the facts of that case because the plaintiff's testimony indicated that he understood the rules of the road and because the bus driver had no way of knowing that plaintiff was mentally retarded. Mr. Fox's knowledge of highway rules can only be

55. Worthington v. Mencer, 96 Ala. 310, 11 So. at 73-74.

56. Fox v. City and County of San Francisco, 47 Cal. App. 3d 164, 120 Cal. Rptr. 779 (1975). 
relevant if the court adopts a dichotomous rule that applies an objective standard to the partially disabled (presumably including Mr. Fox) and a subjective standard for those more severely disabled. But perhaps a better interpretation of the fact's relevance is that it establishes that Mr. Fox's disability was not related to his failure to avoid the accident. While the court appears to use the plaintiff's knowledge as support for holding him to an objective standard, it may be more closely related to the actual holding of the case, which relates to causation:

[T] here is no evidence in the record to support the conclusion that impaired faculties, mental or physical, played any part in causing the collision between the bicycle and the bus. Unless we assume that one's rating on the intelligence chart necessarily plays a part in every accident in which he becomes involved there is no justification in the instant case for giving the impaired faculties instruction. ${ }^{37}$

Courts faced with cases like Fox have agonized over the choice of an appropriate standard of conduct for plaintiffs, and many have chosen the dichotomous rule for reasons that do not demonstrate the inapplicability of a subjective rule to all mentally disabled plaintiffs.

Courts adopting the dichotomous rule appear fearful that if all mentally ill and retarded plaintiffs were held only to a subjective standard of care, they would be able to collect damages for accidents that they could, in fact, have avoided. The concern here is not so much that litigants will feign mental disability as that they will falsely claim that their disability prevented them from taking precautions of which they were, in fact, capable. This concern is not, of course, logically related to the choice between the objective and subjective standard. Even if the subjective standard is applied to a given plaintiff, he will not be absolved from contributory negligence unless it can be shown that his disability "produced" his deficient conduct-that he could not have taken the actions necessary for his protection. ${ }^{58}$ The courts' uneasiness about truly negligent plain-

57. Fox v. City and County of San Francisco, 47 Cal. App. 3d 164, 120 Cal. Rptr. at 784-85.

58. A similar problem has arisen in cases in which druggists are sued for selling the poison with which a mentally ill person attempted or committed suicide. The courts in two cases discussed this as a question of proximate cause. Eckerd's Inc. v. McGhee, 19 Tenn. App. 277, 86 S.W.2d 570 (1935); Riesbeck Drug. Co. v. Wray, 111 Ind. App. 467, 39 N.E.2d 776 (1942). A more straightforward approach (which the courts also pursued in these cases) is to inquire into the disabled person's ability to avoid the injury and thus bring the cases within the framework of contributory negligence.

A more numerous group of cases with somewhat similar fact patterns have chosen to use the contributory negligence analysis. These cases involve the alleged liability of mental institutions for failure to protect patients from self-inflicted harm. These cases are characterized by their solicitude toward the claims of the mentally disabled plaintiffs and focus on the defendants' knowledge of the plaintiffs' disabilities and their special duty to protect them from harm. Among the leading cases in this group are Mochen v. State, 43 A.D.2d 484, 352 N.Y.S.2d 290 (1974) (involving a mentally ill teenager); Avey v. St. Francis Hosp. $201 \mathrm{Kan} .687,442$ P.2d 1013 (1968). Similar facts were analyzed under the doctrine of res ipsa loquitur in Vistica v. Presbyterian Hosp. \& Medical Center, 67 Cal. 2d 465, 432 P.2d 193, 62 Cal. Rptr. 577 (1967). 
tiffs should not be "resolved" by creating a subclass of plaintiffs for whom the issue of "actual negligent conduct" is rendered irrelevant by application of an objective standard.

But whatever the strength of the rationale for a dichotomous rule for contributory negligence, its adoption entails serious administrative difficulties. The main problem is the obvious one of line drawing. The dividing line between "total insanity" and the lesser forms of mental disability may have seemed clear enough to earlier generations of courts. The complexity and subtlety of the various forms of mental illness and mental retardation have now been demonstrated. Establishing a rule that classifies all disabilities into two categories on the basis of severity can be accomplished only by intellectual brute force. To date, no courts have made the attempt.

Should it be thought desirable to create such dividing lines, few possibilities suggest themselves. In the area of mental illness, courts might be tempted to use the demarcation between the psychoses and the neuroses as the division between those disabilities for which a subjective test is employed and those falling under the objective standard. But such a division's clarity would be more apparent than real. Major psychotic disorders have parallel neuroses that manifest many of the same symptoms. ${ }^{59}$ And it will not be the rare case in which each side could produce expert witnesses testifying that the plaintiff's mental disorder was on the advantageous side of the line of demarcation. A casual perusal of the American Psychiatric Association's Diagnostic and Statistical Manual of Mental Disorders ${ }^{60}$ would be likely to convince most observers that such a division would increase rather than decrease the confusion and uncertainty about which the Worthington court was concerned. ${ }^{61}$

Similarly, a dividing line in mental retardation cannot be chosen without cost. This task would appear on the surface to be easier, since all forms of mental retardation, regardless of etiology, can be categorized on a single scale of severity. ${ }^{62}$ Thus all mentally retarded people can be categorized, with whatever degree of accuracy, as mildly, moderately, severely, or profoundly retarded. Courts might thus choose to apply the subjective standard only to those retarded people whose disability falls within the severe and profound categories. But as in the case of mental illness, such a solution does not offer either theoretical clarity or ease of administration and implementation. The categorization of retarded people into the four groups papers over important and complex aspects of their dis-

59. See David Shapiro, Neurotic Styles (New York: Basic Books, Inc., 1965).

60. American Psychiatric Association, supra note 33.

61. See text accompanying notes 54-55 supra.

62. See note 16 supra. 
ability. As has been noted, retardation is a combination of subaverage intellectual functioning with substantial deficits in adaptive behavior ${ }^{63} \mathrm{~A}$ given plaintiff may have intellectual impairment so substantial that it falls within the severe or profound category, but his adaptive behavior may be less seriously affected. Or the reverse may be true. In some tort cases the plaintiff's academic abilities may be more relevant, and in others it may be behavioral factors that are at issue; in a substantial number of cases the relevance of individual factors may be unclear. A dichotomous rule must ignore such subtleties. In addition, various tests are used to measure retardation, and the same test may produce different interpretations in the hands of different professionals. ${ }^{64}$ Thus the rule would certainly produce cases in which expert witnesses disagreed about whether the plaintiff fell on the moderate or severe side of the dividing line. Such testimony would do little to illuminate issues relevant to a fair resolution of the tort case at hand.

In conclusion, it is clear that a dichotomous rule, if applied to a substantial number of litigated cases, would prove difficult to administer. It would invite dispute about difficult technical issues that had little to do with the plaintiff's disability and its relationship to his failure to avoid the accident.

\section{Comparative Negligence}

The radically different treatment afforded mentally disabled plaintiffs and defendants under current law may be even more awkward in those jurisdictions that have adopted comparative negligence. A majority of the states have now either enacted by statute or adopted by judicial decision some form of comparative fault to replace the defense of contributory negligence. ${ }^{65}$ Under comparative negligence, the relative responsibility of plaintiff and defendant for the injury of the former is ascertained by the fact-finder, and the cost of the injury is apportioned accordingly.

No court has addressed the issue of the impact of comparative negligence on the standard of care for mentally disabled litigants. ${ }^{66}$ In dealing

63. Id.

64. A good introduction to the variety of intelligence tests and their uses is found in Halbert B. Robinson \& Nancy M. Robinson, The Mentally Retarded Child (rev. ed. New York: McGraw-Hill Book Co., 1976).

65. In 1980, Professor Goldberg counted 33 states that had adopted some form of comparative negligence. Joseph Goldberg, Judicial Adoption of Comparative Fault in New Mexico: The Time Is at Hand, 10 N.M.L. Rev. 3, 7 (1979-80). Since that time the total has reached at least 35. Claymore v. City of Albuquerque, 20 N.M. St. B. Bull. 289 (Feb. 12, 1981); Alvis v. Ribar, 85 Ill. 2d 1, 421 N.E.2d 886 (1981).

66. Several cases involving mentally disabled litigants have arisen in comparative negligence jurisdictions, but none addresses the question of apportionment of responsibility and the standard of care for the disabled. See Bruenig v. American Family Ins. Co., 45 Wis. 2d 536, 173 N.W.2d 619 (1970); Warner v. Kiowa County Hosp. Auth., 551 P.2d 1179 (Okla. App. 1976); Miller v. Trinity Medical Center, 260 N.W.2d 4 (N.D. 1977). 
with mentally disabled plaintiffs and defendants, courts appear willing to retain the double standard that their jurisdictions adopted under the regime of contributory negligence. Comparative negligence is not totally incompatible with this double standard, and the low number of appealed cases involving the mentally disabled may have made it unnecessary for courts to reconsider this rule. But two factors suggest that such reconsideration might be warranted in comparative fault states.

The first factor is the doctrinal basis of comparative negligence. The allocation of responsibility between the litigants can be seen as the ultimate culmination of the fault ideology in tort law. The system calls for a party to be compensated and/or forced to pay in proportion to the extent of the involved parties' fault. Viewed in this light, it would seem ironic to retain the objective standard for mentally disabled people since that standard is an ill-disguised version of strict liability. It is less than fully convincing to say that a mentally disabled defendant is 70 percent at fault (and thus must pay 70 percent of the damages) because a reasonable (nondisabled) person who acted as the defendant did would have been 70 percent at fault for a similar accident. An objective standard for either plaintiffs or defendants requires the jury to ascertain the degree of a disabled person's responsibility, in pseudo-quantitative terms, for actions over which he had no control. If not incompatible, comparative negligence and the objective standard are at least doctrinally discordant.

The second consideration also relates to the jury's task of allocating responsibility. In cases (most frequently automobile accidents) in which each party sues the other for injuries sustained in the same accident, the double standard between plaintiffs and defendants is at least somewhat awkward. If it finds that both parties contributed to the accident, the jury will have to apportion the responsibility of each party for both his own injury and that of his opponent. In a case in which one party is mentally disabled, the jury will be asked to decide the question of his responsibility for the other party's injury by an objective standard and must then evaluate the same behavior by a subjective standard to determine its role in causing his own injury. Of course, juries in contributory negligence states will have to undertake the same task in cases involving injuries to both parties. But the comparative negligence system's requirement that the fact-finder apportion each party's responsibility highlights the incongruity of evaluating the same actions by two different standards to decide on responsibility for different injuries arising out of the same accident. ${ }^{67}$

67. This incongruity is not unique to cases involving mentally disabled litigants. Courts in comparative negligence jurisdictions have had to consider the appropriateness of utilizing the comparative fault doctrine in products liability cases. E.g., Daly v. General Motors Corp., 20 Cal. 3d 725,575 P.2d 1162, 144 Cal. Rptr. 380 (1978). The concurring and dissenting opinions in Daly raise many of the same problems considered here in the context of mental disability, but the majority con- 
Adoption of comparative negligence does not affect other considerations in the choice between the objective and subjective rules, such as the possibility of fraudulent claims of disability and the specter of the administrative difficulties encountered by the criminal courts. But the doctrinal basis for the objective standard is weakened in comparative negligence states, and the incongruity of treating plaintiffs and defendants differently is more visible and is equally difficult to justify. Therefore it can be argued that the adoption of comparative fault affords an opportunity to consider the desirability of a subjective standard for all mentally disabled litigants in negligence cases.

\section{The ResponsibILITY OF THE Mentally Disabled, Reconsidered}

It is impossible to resolve the issue of the appropriate standard of care for mentally ill and retarded persons without considering their proper standing in society and before the law. Analogies to physically disabled adults and to children must be considered, although neither is perfectly apt. And finally, the question of rights and responsibilities must be raised anew.

\section{A. Analogy to the Physically Handicapped}

The standard of care for physically disabled persons is generally that of a reasonable person "under like disability." ${ }^{68}$ This subjective test means that a paraplegic will not be held to the same abilities as an able-bodied person but will be required to make the same allowances a reasonable paraplegic would make. Thus the physically handicapped are not required to take what would be for them impossible measures for their own protection or for the protection of others.

Several possible reasons can be offered for the difference between the rule for the physically handicapped and that for the mentally disabled. The American Law Institute suggests that the major facts are public acceptance and administrative convenience:

The explanation for the distinction between such physical illness and the mental illness dealt with in $\S 283 \mathrm{~B}$ probably lies in the greater public

cluded that the jury would be able to apportion responsibility even when required to utilize different standards (strict liability for defendant manufacturer and the reasonable person standard for the "contributory" negligence of plaintiff). Viewed from another perspective, the difficulty in using two different standards may say less about the appropriateness of those standards than it says about the conceptual difficulties inherent in the operation of the comparative negligence doctrine itself.

68. Restatement (Second) of Torts $\S 283 C$ (1965). 
familiarity with the former, and the comparative ease and certainty with which it can be proved. ${ }^{69}$

Because of the sharp disparity in the treatment of these two groups under tort law, each of these factors merits closer inspection.

The question of public acceptance presents subtle shadings of difference between perceptions of the two groups. Both mentally and physically handicapped persons are the objects of public concern, largesse, and sympathy. Legislation to assist these groups often treats them similarly and together. ${ }^{70} \mathrm{~A}$ popular image projected by both groups is the sympathy-inducing face of the poster child. But in the case of the mentally disabled, this sympathetic attitude has not always been the dominant public sentiment. As noted earlier, ${ }^{71}$ mentally disabled people were thought to be a major threat to society in the early years of this century. And while the eugenics scare has subsided with the advent of more scientific knowledge about the genetic transmission of mental disability, the previous era of fear has left two relevant legacies. The first is the body of laws designed to restrict the lives of mentally handicapped people in society. ${ }^{72}$ The objective rule of tort liability can be viewed as a minor element in that legislative heritage. The second legacy is a residual fear and discomfort about the mentally disabled. Such fears, although less virulent than they were in the early $1900 \mathrm{~s}$, manifest themselves in the form of opposition to creating group homes in residential neighborhoods ${ }^{73}$ and the current backlash against the practice of "mainstreaming" mentally handicapped children in public school classrooms. ${ }^{74}$ Disorders of the mind remain a source of fear and apprehension in the popular media. This negative side of society's current ambivalence toward the mentally ill and mentally retarded may be what the American Law Institute has in mind when it refers to the public's "greater familiarity" with physical handicaps. $^{73}$

69. Restatement (Second) of Torts § 283C, Comment $b$ (1965).

70. Education for All Handicapped Children Act of 1975, Pub. L. No. 94-142, 89 Stat. 773, 20 U.S.C.A. $\$ \$ 1401-61$ (West 1978); Rehabilitation, Comprehensive Services, and Developmental Disabilities Amendments of 1978, Pub. L. No. 95-602, 92 Stat. 2955, 29 U.S.C.A. § 706(7)(B) (West 1980 Supp.).

71. See text accompanying notes 29 and 30 supra.

72. See generally Paul R. Friedman, The Rights of Mentally Retarded Persons (New York: Avon Books, Discus Books, 1976); Patricia M. Wald, Basic Personal and Civil Rights, in President's Committee on Mental Retardation, supra note 5 at 3.

73. Robinsue Frohboese \& Bruce Sales, Parental Opposition to Deinstitutionalization: A Challenge in Need of Attention and Resolution, 4 Law \& Human Behavior 1 (1980); Robert B. Kugel \& Ann Shearer, eds., Changing Patterns in Residential Services for the Mentally Retarded (rev. ed. Washington, D.C.: President's Committee on Mental Retardation, 1976).

74. Id.

75. See generally Robert B. Edgerton, The Cloak of Competence: Stigma in the Lives of the Mentally Retarded (Berkeley: University of California Press, 1967). For a comparative view of American 
Granted that there is a difference in public attitude toward physical and mental handicaps, the relevance of that difference to the tort standard is less than perfectly clear. The AlI's discussion of "public familiarity" would explain the differences if the rules were a creation of juries, but juries only apply a standard they receive from judges. One possible interpretation of the ALI comment is that judges, as members of the public, are less familiar with mental disability and are therefore less willing to include them within the subjective standard. The other available interpretation is that judges, as public officials, believe that the average citizen would react unfavorably to the extension of a subjective test to the mentally disabled. Since our system of justice is supposed to reflect the societal consensus of what is fair and equitable, it may be thought that the general public would be offended by a system that denied recovery to plaintiffs injured by mentally disabled persons who were unable to perform at the high standard of care of the reasonable person. Empirical data on this point are unavailable, but it is at least conceivable that public sentiment is more sympathetic toward physically disabled defendants than to their mentally disabled counterparts. Whether that difference in degrees of sympathy is sufficient to support the different standards of care applied to the two groups is open to debate.

The other rationale offered by the ALI is that a physical handicap can be identified with greater ease and certainty than mental disability. Thus the courts that fear the replication of the difficulties that accompany the insanity defense in criminal law $^{76}$ are less concerned that similar administrative and evidentiary problems will arise in cases involving the physically handicapped. It is certainly true that deafness, blindness, and quadriplegia in litigants are easier to ascertain than the subtler forms of mental illness. On the other hand, severe or profound mental retardation may present fewer proof problems than partial hearing loss, restricted vision, or a neurological condition that retards physical reflexes.

Whether mental and physical handicaps are so similar that they should be treated in similar fashion by the tort law remains debatable. In considering this question, it should be remembered that the form of the subjective standard for the physically disabled incorporates the individual's knowledge of his own handicap. Thus a blind person is required to act as a reasonable blind person would act, which includes taking his own blindness into account in planning his activities. The ability to plan "around" the disability will be available less frequently for mentally dis-

and European attitudes, see Leopold Lippman, Attitudes Toward the Handicapped: Comparison Between Europe and the United States (Springfield, Ill.: Charles C. Thomas, Publisher, 1972).

76. See text accompanying notes $39-41$. 
abled persons. The fact that it is the individual's mind that is affected will reduce the occasions when the person can identify that his disability is likely to create hazardous situations for himself or others. Such occasions are not impossible in all cases-a retarded person may know that his disability makes it unwise to engage in a particular activity that his teaching suggests is associated with danger. But such instances will be rarer for the mentally retarded and mentally ill than they are for the physically handicapped who suffer no substantial mental impairment. ${ }^{77}$ A subjective standard for the mentally handicapped could include the same sort of limitation, but "the reasonable person with similar mental handicap" is a formulation that is at least initially confusing for courts and juries, and there will be many cases in which it would not represent any modification of the pure subjective standard- "what was this individual capable of doing to avoid the injury?"

The one judicial attempt to draw an analogy between the physically and mentally disabled is so limited in scope that it does not serve as a very useful indicator of the possible utility of the analogy on a wider scale. In Bruenig v. American Family Insurance Co. ${ }^{78}$ the Wisconsin Supreme Court decided that while the objective standard would continue to apply to most cases of mental disability, cases involving sudden onset of insanity should be analogized to sudden heart attacks that cause accidents. Thus when the sufferer of either of these disabilities has no warning of its likelihood (presumably measured by a previous occurrence or other medical indication that the person was prone to such attacks) he will be absolved from responsibility for a resulting accident on the theory that he could not have avoided it. ${ }^{79}$ Bruenig remains a less than satisfactory resolution not because it deals unfairly with the person who suffers a sudden attack of insanity (such as a compelling delusion) or with his "victim" but rather because its attempt to distinguish these cases from others involving less sudden mental disability is unpersuasive. This distinction fails because it presupposes that only those whose mental handicap is of sudden onset are in fact unable to control their actions. Common experience

77. The Massachusetts Supreme Judicial Court grappled with a similar issue in determining the appropriate test for substituted judgment when a profoundly retarded man was proposed for lifeprolonging (but not life-saving) chemotherapy for leukemia. The court ruled that the substitute decision maker should decide as the disabled person would have decided for himself if competent and if he were able to take into account the effects of his own incompetence. Superintendent of Belchertown v. Saikewicz, 373 Mass. 728, 370 N.E.2d 417 (1977).

78. 45 Wis. 2d 536, 173 N.W.2d 619 (1970).

79. Accord, Buckley and Toronto Transp. Comm'n. v. Smith Transp., Ltd., 1946 Ont. L. Rep. 798, [1946] 4 D. L. Rep. 721 (1946). Other courts in the United States have reached the opposite conclusion and ruled that no exception to the objective standard is warranted. Sforza v. Green Bus Lines, Inc. 150 Misc. 180, 268 N.Y.S. 446 (1934); Kuhn v. Zabotsky, 9 Ohio St. 2d 129, 224 N.E.2d 137 (1967). 
suggests that many mentally ill and mentally retarded persons whose condition has been previously diagnosed and identified remain incapable of taking their disability into account sufficiently to conform their actions to a modified reasonable person standard. The Bruenig court's analogy to those suffering sudden physical disability is a less than satisfactory half-measure that carves out an exception to the objective standard for only a few mentally disabled defendants. But it does so based on a policy that, if applied evenhandedly, would result in a subjective standard for the vast majority of mentally handicapped defendants.

\section{B. Analogy to Children}

Even greater conceptual and ideological difficulties arise when one attempts to analogize the negligence standard of mentally disabled adults to that of mentally typical children. Yet despite these difficulties, the comparison remains attractive, if not seductive, and courts should analyze the issue carefully before deciding whether to employ the analogy.

The general rule is that children are held to a subjective standard. It is most frequently stated as that conduct which it is reasonable to expect of children "of like age, intelligence, and experience." emerged only after the courts had long rejected the notion of immunity of infants for their torts. ${ }^{81}$ It developed first in contributory negligence cases and was then extended to those cases in which children were the defendants. ${ }^{82}$ In contrast to the objective standard for adult defendants, it requires more than average care from the child of superior ability and less from the child of limited ability. Our attention is drawn, of course, to the latter aspect of the standard. ${ }^{83}$

The subjective rule for children is defended by the American Law Institute as a sympathetic doctrine that presents no great difficulties of administration:

The special standard to be applied in the case of children arises out of the public interest in their welfare and protection, together with the fact that there is a wide basis of community experience upon which it is possible, as a practical matter, to determine what is to be expected of them. ${ }^{84}$

As was noted in the previous section, public attitudes about the mentally ill and mentally retarded have included substantial elements of fear and

80. Restatement (Second) of Torts $\S 283 A$ (1965).

81. Prosser, supra note 26, at 996.

82. See 2 Fowler V. Harper \& Fleming James, Jr., The Law of Torts 926 (Boston: Little, Brown \& Co., 1956); Prosser, supra note 26, at 156.

83. For adults of superior ability, the only exception to the objective reasonable person standard is that some professionals, such as surgeons, will be held to the standard expected of their similarly situated colleagues, rather than to the lay person's knowledge of anatomy, for example.

84. Restatement (Second) of Torts \& 283A, Comment $b$ (1965). 
revulsion, and even today's enlightened attitudes are not without a certain amount of ambivalence, so it can be argued that "the public interest in their welfare and protection" is less emphatic than is true in cases involving children. Nevertheless, it is difficult to deny that there has developed some sort of consensus that mentally disabled people are entitled to public concern and some form of protection. Therefore, the first element of the Restatement's defense seems insufficient to distinguish the case of the mentally handicapped adult.

The second element of that defense-that a subjective test may be administered practicably - presents the more substantial impediment to the analogy. Commentary to the Restatement emphasizes that our common experience provides sufficient information about what children of various ages can be expected to do, thus rendering a subjective standard workable. It is certainly true that jurors are more likely to have informative experience about the abilities of children than they are about various forms of mental disability. Therefore the key issue is whether expert testimony can provide sufficient assistance to jurors to allow them to implement a subjective test for mentally handicapped adults.

It is important to note that the child standard itself requires the jury to inquire into the subjective state of children "of like . . . intelligence." In a case involving a mentally retarded child, for example, the fact-finder would have to determine what a reasonable child with intelligence comparable to the defendant's would have done in a similar situation. This inquiry does not differ substantially from the question presented in the case of a mentally retarded adult defendant if the latter were also to be measured by a subjective standard. No greater degree of evidentiary complexity attends the case simply because the mentally retarded defendant has attained majority. Nor is it likely that jurors' experience with mentally retarded children is significantly greater than their acquaintance with mentally retarded adults; most jurors will have had little or no experience with either. Thus, insofar as the mentally retarded are concerned, there appears to be no valid argument against a subjective standard that does not apply equally in cases involving children-cases that are already tried under a subjective test.

Cases involving mental illness present somewhat different issues. The Restatement's commentary on the child standard points out that the phrase "of like . . . intelligence" does not refer to all aspects of mental functioning:

"Intelligence" includes other mental capacities, but does not include judgment, which is an exercise of capacity rather than the capacity itself. The fact that the child is mentally retarded, or that he is unusually bright for his years, is to be taken into account; but once such account is taken, the 
child is still required to exercise the judgment of a reasonable person of that intelligence. ${ }^{8 s}$

To what extent are the distortions of normal mental functioning which result from the various forms of mental illness to be attributed to substandard judgment? If the defendant in a negligence case suffers from a delusion that his bodily movements are being controlled by someone other than himself, should this factor be considered under the heading of impaired judgment or under some other classification of mental pathology? Such line drawing is a difficult task for courts and one in which they can anticipate little or no useful assistance from the expertise of the medical profession. While the psychiatric profession also talks about "impaired judgment," issue.

The apparent purpose of this limitation is to disallow a defense that the defendant habitually makes poor choices that result in accidents and should thus be absolved from responsibility. This has analogies elsewhere in the law. The subjective negligence standard for physically handicapped adults will not be available to a defendant whose only claim is that he is unusually accident prone. ${ }^{87}$ Similarly, the criminal law has resisted extension of the insanity defense to "psychopaths" whose only manifestation of mental illness is their habitual criminal behavior ${ }^{88}$ Necessarily, the claims of mental disability would require similar scrutiny under a subjective test, but this kind of inquiry is similar to cases that the courts already handle in these other areas.

It would thus appear that implementation of a subjective standard of care for mentally ill and mentally retarded defendants would not entail difficulties beyond those that are already accepted under the subjective standard applied to children. ${ }^{89}$ There remains, however, the question of whether the similarities between the two groups are sufficient to persuade the courts that they would be treated the same way by rules of responsibility for negligence.

85. Id. at 15 .

86. See generally, American Psychiatric Association, supra note 33.

87. See generally, Fleming James, Jr. \& John J. Dickinson, Accident Proneness and Accident Law, 63 Harv. L. Rev. 769 (1950).

88. American Law Institute, Model Penal Code § 4.01(2) (Proposed Official Draft, 1962); but see Wade v. United States, 426 F.2d 64 (9th Cir. 1970).

89. One problem that the courts have confronted in cases involving children is the matter of driving automobiles and other vehicles. Courts have generally concluded that when a child engages in such "adult" activity, he will be held to an objective adult standard and will not be able to use the defense that normally would be his because of his youth. Prosser, supra note 26, at 156-57. This rule arose from concern about public safety. Similar concerns may be involved in the creation of a similar exception to a subjective standard for mentally disabled adults-that they will not be excused from negligence when they violate traffic laws. See Criez v. Sunset Motor Co., 123 Wash. 604, 213 P.7 (1923). 
The comparison of mentally retarded adults with children is particularly attractive..$^{90}$ Retarded adults are often viewed as persons whose childhood mental development was slower than average and at some point stopped short of the intellectual ability that other adults attain. This manner of thinking about mentally retarded people is reinforced by the availability of tests to measure the retarded person's intellectual skills in terms of "mental age." This concept expresses the retarded individual's mental ability in comparison to that of mentally typical children. It accomplishes this by taking the individual's IQ score and matching it with the chronological age at which mentally typical children usually attain the same score. For example, an adult whose intellectual development as measured by IQ tests is about the same as that of a mentally typical three-year-old child will be said to have a mental age of three years. ${ }^{91}$

The notion of mental age has a certain seductive simplicity to it. A court may be perplexed when it hears testimony that a litigant falls within the moderately retarded level of disability. But if the testimony describes that same adult as having a mental age of three years, the court may feel reassured because all of us have some notion about the abilities and disabilities of three-year-olds. The same court that is uncertain as to whether a profoundly retarded adult should have known that his actions might start a fire, may feel more comfortable in deciding whether a three-yearold (or his adult retarded equivalent) should have known. Thus in tort cases, as well as in other areas of the law, the mental age concept may be viewed as a useful judicial tool in understanding (and helping juries understand) how to apply a subjective standard or to otherwise evaluate the actions of a retarded person.

Although the simplicity of the mental age notion makes it helpful in understanding the intellectual abilities of a retarded adult, ${ }^{92}$ it does not give the court a full picture of the individual and therefore has the potential to obscure rather than clarify. Mental age describes the individual only in terms of his intellectual skills, which roughly translated means how well he can do in learning certain academic lessons commonly learned in childhood. It can be useful in describing the adult's ability to learn arithmetic or to acquire and use vocabulary. To the extent that these

90. This is true not only in law but in societal attitudes generally. Retarded adults are often thought of (and treated) as children who never grew up. They are frequently addressed and referred to as "boys" and "girls," even when they are middle aged and older. See text accompanying note 92 infra.

91. Robinson \& Robinson, supra note 64. See also Frank J. Menolascino, ed., Psychiatric Approaches to Mental Retardation 717-19 (New York: Basic Books, Inc., 1970).

92. It is also used, of course, with mentally retarded children. Thus a child with a chronological age of 12 may be said to have a mental age of 3 . 
skills or their equivalent are relevant to the defendant's actions in causing the accident in question, the concept is useful. But to say that a retarded adult has a mental age of three is not to say that he is in other ways equivalent to a three-year-old. The adult has lived much longer and has an adult's body. His experiences will have had a substantial impact on his knowledge and skills. A three-year-old is unlikely to have lived in society outside the confines of his family, but the adult may or may not have. Courts must thus be careful not to let the artificial notion of mental age, as simple and convenient as it may seem, substitute for a full inquiry into the actual abilities and experience of the adult whose actions are at issue.

This raises the larger philosophical issue regarding the analogy between children and retarded adults. The simple fact is that retarded adults are adults; they are not children. Society has often treated them as children, and this has proven damaging at least as often as it has been beneficial. ${ }^{93}$ The dominant current ideology among professionals who work with retarded people is called normalization, ${ }^{94}$ and it includes the belief that, as much as possible, retarded people should be treated like other people of their chronological age. This notion of age appropriateness is applied to living arrangements, work situations, recreation, clothing, social relationships, and terminology (retarded adults are not "boys" and "girls"). Whether normalization should lead us to resist treating retarded adults under the same kind of legal rules ordinarily applied to children but not to mentally typical adults is a question that the proponents of normalization have not yet addressed.

\section{The Utility of Analogies}

It appears that analogies between mentally disabled adults on the one hand and children or physically handicapped adults on the other are helpful tools. But ultimately they cannot resolve the question of the proper standard of care for mentally disabled tort litigants. No substantial barriers prevent the adoption of the subjective standard already applied to these other groups. But neither of the analogies is so perfect that it is selfevident that manifest injustice is done when courts refuse to apply a subjective standard to mentally handicapped adults. The question of the responsibility of mentally disabled people for their torts must be considered on its own merits.

93. See generally Wolf Wolfensberger, The Principle of Normalization in Human Services (Toronto: National Institute on Mental Retardation, 1972).

94. William G. Bronston, Concepts and Theory of Normalization, in Richard Koch and James Dobson, eds., The Mentally Retarded Child and His Family: A Multidisciplinary Handbook 490 (rev. ed. New York: Brunner/Mazel, Inc., 1976). 


\section{The Rights and Responsibilities of the Mentally Disabled}

The observation that rights and responsibilities must exist in balance is among the most grating of clichés. But as if often the case, it attained its status as a cliché by containing an element of truth. Since the era in which the current objective standard was adopted, our view of the rights of mentally disabled people and of their status before the law has changed dramatically. With the exception of the area of criminal law, we have given less consideration to the question of what level of responsibility can be expected of our mentally disabled citizens. The reconsideration of standards of care in negligence cases affords us such an opportunity.

Society has accepted, however unevenly and grudgingly, the principle that greater numbers of mentally ill and retarded people should be allowed to live in society with a minimum of supervision. We no longer expect (or wish) the majority of the mentally disabled to live in institutions far removed from the rest of us. These new expectations are grounded in an acceptance of the full citizenship rights of mentally handicapped people. This will surely result in an increasing number of accidents caused by such disabled people; all groups cause such accidents, and it would not be too surprising if mentally disabled people caused somewhat more than their share. Whether they should bear the costs of these accidents in cases in which their prevention was beyond the individual's capacity is a question of both equity and compensation. Is it less fair to ask accident victims (or their insurers) to bear the costs of injury when caused by mentally disabled persons than it is in cases involving children or the physically handicapped? Can we accept as just a rule that holds mentally handicapped people to a standard of care which they are incapable of meeting? Thoughtful consideration of these questions may suggest the renewed attractiveness of a subjective test.

Courts must also be sure that the rules they adopt are reasonable and defensible. The rationales for the objective standard have been weakened by the events of recent decades. If the standard is to be retained, it must be supported by a more contemporary defense. ${ }^{95}$ One element remaining from the original rationales is the contention that introducing subjective considerations will burden the courts out of proportion to any anticipated gains in perceived fairness. The burdens are not insubstantial, but the courts' task under a subjective standard would not differ markedly from tasks already undertaken in other legal contexts.

95. One attempt at a renewed defense of the objective standard for the mentally ill is found in Alexander \& Szasz, supra note 19. The authors base their defense upon a theory of moral responsibility. Whatever its attractiveness in cases involving the mentally 111 , it would probably find less acceptance in cases involving the mentally retarded. 
A more contemporary defense of the objective test might argue that since normalization calls for retarded adults to be treated like other adults, they should be held to the same objective standard that applies to other adults. The problem with this argument is that mentally typical adults are not held to a standard that they are definitionally incapable of meeting. The normalization principle can also be invoked to support a subjective test; mentally typical adults are treated under a standard of care which is within the abilities of most of them, and retarded adults should receive no less consideration. Thus, as currently articulated, the normalization principle appears to offer little guidance in resolving the larger issue.

Under modern conditions, the subjective standard may be preferable. It does not immunize mentally disabled people from responsibility for their torts, but it does provide them with a defense when they can show that they did their best to avoid the accident and that further preventive measures were beyond their ability. It could be framed in such a way as to measure a disabled defendant against the standard of what a reasonable adult of similar experience and intelligence would have been able to do. Holding the defendant to a higher standard can provide no deterrence to accident-causing behavior; if the defendant is capable of avoiding the accident he will be held accountable for failing to exercise that capability. Adoption of this standard would create a class of plaintiffs who cannot obtain recovery from the person who caused the injury, but it does so in the same manner as is now the case with children and the physically handicapped. Our fault system, in rejecting strict liability, accepts the plight of such plaintiffs as the regrettable but necessary cost of doing justice to defendants who performed to the best of their ability.

Should courts choose to adopt such a subjective standard, they would then face the task of determining the formulation of proper jury instructions concerning the degree of disability and other matters of importance. None of these tasks is without difficulty, but none is more complex than those already facing courts in other areas of mental disability law. Mental disability and the status of mentally disabled people before the law are complex matters, and no simple solutions will achieve justice for mentally disabled citizens or for their opponents in litigation.

\section{CONCLUSION}

The objective standard of care for mentally disabled defendants was an outgrowth of the ideology of confinement-an ideology that society has since abandoned. The rule has remained in force because very little litigation involving such defendants has reached the appellate courts and 
because no alternative of stunning superiority has presented itself. Adoption of a subjective standard would not right a vast number of grave injustices, nor would it dramatically ease the burdens of the courts. It would probably have no effect on the overall number of accidents in society, nor would it significantly shift the burden of their cost. But on balance, it may be seen as a modest step toward equitable treatment of the mentally handicapped before the law. 